\title{
An Unmitigated Disaster: Shifting from Response and Recovery to Mitigation for an Insurable Future
}

\author{
Eliza de Vet $^{1} \cdot$ Christine Eriksen $^{1} \cdot$ Kate Booth $^{2} \cdot$ Shaun $^{\text {French }}{ }^{3}$
}

Published online: 3 April 2019

(C) The Author(s) 2019

\begin{abstract}
Australian households are increasingly vulnerable to natural hazard-related disasters. To manage disaster risk, government commissioned inquiries have called for greater investment in mitigation. This article critically examines the call for a shift in funding priority towards pre-disaster mitigation measures, in the context of growing concerns around the ability of households to access and afford insurance. It examines mitigation measures in the context of three prominent Australian disasters: the Black Saturday bushfires (Victoria, 2009), the Queensland floods (2010-2011), and Cyclone Yasi (Queensland, 2011). We argue that as a mode of disaster security, mitigation operates as a complex assemblage of logics and practices of protection, preparedness, and resilience, which problematizes simplistic protection/resilience binaries. On the one hand, mitigation serves as a mode of protection, which underscores the dominant maladaptive rationality of insurance. It promises a collective solution to uninsurability that is limited by government fiscal constraints and growing employment of risk-reflective insurance pricing. On the other hand, there is evidence of an emergent rationality of household insurance as a path to resilience and preparedness-for example, in the development of
\end{abstract}

Christine Eriksen

ceriksen@uow.edu.au

1 Australian Centre for Culture, Environment, Society and Space (ACCESS), School of Geography and Sustainable Communities, Faculty of Social Sciences, University of Wollongong, Wollongong NSW 2522, Australia

2 Geography and Spatial Science, University of Tasmania, Hobart TAS 7001, Australia

3 School of Geography, Faculty of Social Sciences, University of Nottingham, Nottingham NG7 2RD, England insurance systems that price household retrofitting technologies and in the development of policyholder education campaigns. This resilience rationality holds the promise of securing individuals previously excluded from insurance. However, for householders lacking the necessary physical, cognitive, and financial capacities to make themselves and their properties resilient, the transition to a pre-disaster mitigation mode of security will likely do little to alleviate disadvantage and marginalization.

Keywords Australia $\cdot$ Disaster mitigation - Household insurance $\cdot$ Household marginalization $\cdot$ Household resilience $\cdot$ Natural hazards

\section{Introduction}

Most governments prioritize disaster response and recovery over risk reduction and mitigation. In Australia and the United States respectively, $3 \%$ and $4 \%$ of disaster spending goes towards mitigation (Coppel and Chester 2014; Cigler 2017). Less than 40 cents of every 100 US dollars of international aid is allocated for disaster risk reduction or mitigation $^{1}$ (Kellett and Caravani 2013). This expenditure and investment pattern negatively impacts insurability, particularly in the context of rising disaster costs. In 2017, there were 330 natural hazard-related disasters globally (97\% were weather-related), resulting in an estimated economic loss of USD 353 billion (Aon Benfield 2018). In the same year, Australian disaster costs reached USD 9.8 billion, a cost set to double by 2038 (DAE 2017). Australia

\footnotetext{
$\overline{1}$ All figures in this article refer to US Dollars unless stated otherwise. At the time of writing 1 Australian Dollar equaled 0.74 US Dollars (xe.com, 30 July 2018).
} 
is prone to disasters, such as bushfires, floods, cyclones, droughts, heatwaves, and storms. In the 10 years leading up to 2016, the total economic cost of such disasters averaged USD 13.5 billion per annum, which includes both tangible costs (for example, emergency response and property damage) and intangible costs (for example, death and impacted community connectedness) (DAE 2017). As the costs of disasters rise globally, there is increasing contention around how disaster funding is allocated (Kellett and Caravani 2013; Cigler 2017). National resilience strategies in Australia (and elsewhere) heavily skew federal, state, and territory disaster spending towards response and recovery, rather than mitigation measures taken in advance of disasters to decrease or eliminate social and environmental impacts (COAG 2011; DAE 2013; Coppel and Chester 2014). These measures, such as flood levees, early warning systems, and education programs implemented in Australia and internationally, have notable proven long-term financial returns, but financial outlay competes with post-disaster priorities (Shreve and Kelman 2014; DAE 2017).

Over the last decade, critical scholars have pursued the politics of resilience strategies, tracing the ways resilience has come to increasingly dominate disaster and emergency thinking and planning (Chandler and Coaffee 2016). Theorists have argued that we are witnessing an historical reconfiguration of the rationalities of liberal governance, such that "liberalism is aimed today not at solving or preventing the manifestation of dangers and threats to security, but at making us forego the very idea and possibility of security" (Evans and Reid 2014, p. 2). Enhancing community and individual adaptive capacity is central to the doctrine of resilience, which emphasizes the need to accept and even embrace the unpredictability and uncertainty of natural hazards in an increasingly complex and interconnected world (Jon 2018; Sword-Daniels et al. 2018). The United Nations International Strategy for Disaster Reduction (UNISDR 2016) embeds resilience within a broad definition of mitigation, which includes engineering techniques, hazard-resistant constructions, environmental and social policies, and public awareness. The lack of such measures in current post-disaster reactionary approaches exposes Australia and other nationstates to escalating costs, as little investment is made to reduce the impact before disaster strikes. However, recent disasters in the Australian states of Victoria and Queensland have acted as a catalyst for regional mitigation initiatives and strategies.

Informed by critical security literature, this article analyzes the nature of calls for, and the politics of, disaster mitigation in Australia. We argue that Australia provides an important case study for building an understanding of change in disaster spending and mitigation theorizing, in the context of growing concerns over household insurability. Despite the extensive body of scholarship on resilience, mitigation as a rationality of security remains insufficiently studied. The article presents a detailed review of government inquiries and commissions, policy documents, and academic work on mitigation in the context of the Black Saturday bushfires (Victoria, February 2009), the Queensland floods (December 2010-January 2011), and Cyclone Yasi (Queensland, February 2011).

We make two main arguments. We argue that as a mode of disaster security, mitigation operates as a complex assemblage of logics and practices of protection, preparedness, and resilience. We add weight to scholarship that has problematized an oft assumed protection/resilience binary (see, for example, Aradau 2014). We then consider the impact of a government shift in funding priority towards disaster mitigation spending on the politics of insurability, and on the reliance on insurance as a principal strategy for households to manage disasters. We argue that insurance as resilience produces new iniquities, disregarding those without resources to make themselves resilient and those whose resourcefulness cannot be marketized (Aradau 2014; Cooper 2015).

We start by examining recent disasters and how households fared under a post-disaster approach to spending, outlining the respective roles of government, welfare organizations, and the insurance sector in disaster relief and recovery. We then explore the argument for mitigation set out in recent government commissioned inquiries into disaster funding in northeastern and southeastern Australia, why support for pre-disaster spending remains relatively limited, and what greater investment in pre-disaster risk management could look like within current climates of "shared responsibility." In undertaking a close reading of existing and proposed flood, cyclone, and bushfire mitigation projects, as well as mitigation recommendations from Queensland and Victoria State Government reports, we examine the politics of disaster mitigation that work at the intersection of protection and resilience, and consider the implications in terms of insurability problems.

\section{Households and Home Insurance in Recent Disasters in Australia}

Among the costliest disasters in Australia are the 2009 Black Saturday bushfires (Victoria), the 2010-2011 Queensland floods, and 2011 Cyclone Yasi (Queensland). Their respective costs were estimated at USD 3.0 billion (response and damage costs; Teague et al. 2010), USD 3.7 billion (reconstruction costs; Holmes 2012), and USD 1.1 billion (property damage costs; DAE 2017). On a regional scale, these figures are quite modest, but they represent a microcosm of global trends (Table 1). 
Table 1 Financial breakdown of select disaster events in billion US dollars

\begin{tabular}{|c|c|c|c|c|}
\hline Disasters & $\begin{array}{l}\text { Total } \\
\text { loss }\end{array}$ & $\begin{array}{l}\text { Underinsurance } \\
\text { gap }\end{array}$ & $\begin{array}{l}\text { Insurance } \\
\text { claims }\end{array}$ & $\begin{array}{l}\text { Post-disaster government } \\
\text { expenditure }\end{array}$ \\
\hline US hurricanes (Wilma, Rita, Katrina) 2005 & 170 & $62 \%$ & - & 29.76 \\
\hline UK flooding 2007 & 3.4 & $38 \%$ & & 0.174 \\
\hline Chinese earthquake (Sichuan) 2008 & 125 & $99 \%$ & 0.366 & 137.5 \\
\hline $\begin{array}{l}\text { Japanese earthquake-tsunami (Tohoku) and nuclear disaster } \\
\text { (Fukushima) } 2011\end{array}$ & 210 & $83 \%$ & - & 279.25 \\
\hline Thailand floods 2011 & 30 & $60 \%$ & & 13 \\
\hline Australia Black Saturday bushfires 2009 & $2.97^{\mathrm{a}}$ & - & $0.74^{\mathrm{a}}$ & - \\
\hline Australia Queensland floods 2010-2011 & $3.72^{\mathrm{b}}$ & - & $1.77^{\mathrm{b}}$ & - \\
\hline Australia Cyclone Yasi 2011 & $0.59^{\mathrm{b}}$ & - & $1.04^{\mathrm{b}}$ & - \\
\hline
\end{tabular}

Blank cells indicate no data. Figures in this table have been drawn from diverse sources and have been calculated using different logics. They should be read as indicative only

Sources Edwards and Davis (2012); ${ }^{\mathrm{a}}$ Teague et al. (2010); ${ }^{\mathrm{b}}$ DAE (2013), Holmes (2012), Queensland Cabinet and Ministerial Directory (2011)

\subsection{The Role of Government Assistance in Disaster Relief and Recovery}

The Black Saturday bushfires were Australia's deadliest and most costly bushfires in history: 173 people lost their lives, 414 people were injured, one million acres of land burned, and 2029 homes were destroyed (out of a total of 3059 structures damaged or destroyed) (Eriksen 2014). Of the homes damaged by fire, $87 \%$ were covered by some level of home and contents insurance (Teague et al. 2010). As part of Australia's post-disaster focus, impacted households, regardless of insurance payments, received financial assistance from federal and state governments, as well as charitable organizations (Table 2).

Eighteen months after Black Saturday, $99 \%$ of Queensland was affected by floods and/or Cyclone Yasi: 37 people died, 2.5 million people were affected, and over 26,500 residential home insurance claims were made (Holmes 2012; DAE 2017). Because the floods and the cyclone occurred in quick succession, both events were treated as the same emergency by the state of Queensland. As with the Victorian bushfires (Table 1), households had access to a range of government and community-raised funds, some of which took insurance payouts into account (Table 3). While insurance-based deductions raise moral hazard concerns, they avoid households financially profiting from disasters and targets those most in need (Trowbridge et al. 2011). This includes Queensland households who did not have access to affordable insurance (TAGT 2015).

\subsection{Insuring Disaster Relief and Recovery}

Despite significant government funding post-disaster, most households depend on insurance in their recovery. On average, insurers in Australia cover nearly USD 900 million in disaster losses each year (DAE 2013) for an estimated $96 \%$ of households with home insurance, and $71 \%$ of households with contents insurance (29\% of households had no contents insurance) (Tooth 2015). Black Saturday alone resulted in USD 740 million in insurance claims (Teague et al. 2010). Another USD 1.8 billion and USD 1 billion were claimed respectively for the Queensland floods and Cyclone Yasi (DAE 2013). While payments were substantial, there were high levels of underand noninsurance, which in the case of Black Saturday was found to have "stifled" the recovery process (Teague et al. 2010, p. 339). Lloyd's Global Underinsurance Report (Edwards and Davis 2012) estimated underinsurance for each disaster in Australia between 2004 and 2011 at USD 83 million.

Private insurance is key to Australia's overall National Strategy for Disaster Resilience (COAG 2011), as is common within industrialized nations, including the United Kingdom (UK), the United States (US), France, and New Zealand (NZ) (Krieger and Demerritt 2015; Worthington 2015). In national disaster reports (Teague et al. 2010; Trowbridge et al. 2011; Holmes 2012), insurance is understood as a disaster response mechanism rather than a preparedness measure, because it addresses perceived shortcomings and limits of mitigation strategies, including land-use planning, building standards, and regulations (Booth and Williams 2012). To this end, current public campaigns in Victoria are promoting insurance as an "absolute necessity" (Victorian State Government 2017).

While the Australian insurance market is said to be "working well" (Coppel and Chester 2014, p. 2), and insurance enables households to be more resilient, there are several issues that appear to limit its efficiency and longterm sustainability. In contrast to the centrality of insurance in government disaster management, insurer promotion of 
Table 2 Post-disaster impacted household funding, 2009 Black Saturday bushfires (Victoria)

\begin{tabular}{|c|c|c|c|}
\hline Payments & Funding source & Payment type & Payment \\
\hline $\begin{array}{l}\text { Australian Government } \\
\text { Disaster Recovery } \\
\text { Payment }\end{array}$ & $\begin{array}{l}\text { AU\$65.4 million }{ }^{\mathrm{c}}- \\
\text { Federal Government }\end{array}$ & & $\begin{array}{l}\text { AU } \$ 1000 \text { per adult; } \\
\text { AU } \$ 400^{\mathrm{a}} \text { per child }\end{array}$ \\
\hline \multirow{7}{*}{$\begin{array}{l}\text { Victorian Bushfire Fund } \\
\text { Appeal }(\mathrm{AU} \$ 402 \text { million } \\
\left.\text { incl. interest }{ }^{\mathrm{b}}\right)\end{array}$} & \multirow{7}{*}{$\begin{array}{l}\text { AU } \$ 4 \text { million }^{\mathrm{a}} \text { - equal } \\
\text { state and federal } \\
\text { contributions; } \\
\text { AU } \$ 375 \text { million } \\
\text { donations }\end{array}$} & $\begin{array}{l}\text { Household repairs (short } \\
\text { term) }\end{array}$ & AU $\$ 3000$ per household ${ }^{\mathrm{d}}$ \\
\hline & & $\begin{array}{l}\text { Rehousing and recovery } \\
\text { (destroyed homes) }\end{array}$ & $\begin{array}{l}\text { AU } \$ 35,000 \text { per household; + AU } \$ 15,000 \text { contents; } \\
\quad(+ \text { AU } \$ 50,000 \text { needs based })^{\mathrm{d}}\end{array}$ \\
\hline & & $\begin{array}{l}\text { Rehousing and recovery } \\
\text { (damaged homes) }\end{array}$ & AU $\$ 15,000$ per household $\left(+A U \$ 20,000\right.$ needs based) ${ }^{\mathrm{d}}$ \\
\hline & & $\begin{array}{l}\text { Rehousing and recovery } \\
\text { (tenants) }\end{array}$ & AU $\$ 15,000$ per household $(+\$ 20,000 \text { needs based })^{\mathrm{d}}$ \\
\hline & & $\begin{array}{l}\text { Winter needs (destroyed or } \\
\text { damaged homes) }\end{array}$ & AU $\$ 2000$ per household ${ }^{d}$ \\
\hline & & $\begin{array}{l}\text { Support for boarders to } \\
\text { rehouse }\end{array}$ & AU $\$ 5000$ for $<2$ people; AU $\$ 7500$ for $3+$ people $^{\mathrm{d}}$ \\
\hline & & Transitional support & $\begin{array}{l}\text { Homeowners: AU } \$ 10,000 \text { singles/couples; AU } \$ 15,000 \\
\text { family of } 3+\text {; Renters: AU } \$ 5,0001-2 \text { residents; } \\
\text { AU } \$ 75003+\text { residents }^{\mathrm{d}}\end{array}$ \\
\hline \multirow[t]{4}{*}{$\begin{array}{l}\text { Victorian and } \\
\text { Commonwealth } \\
\text { Payments (NDRRA) }\end{array}$} & AU\$5 million ${ }^{c}$ & $\begin{array}{l}\text { Reestablishment (Structures) } \\
\text { Grants for structural } \\
\text { property damage }\end{array}$ & 640 successful applications \\
\hline & AU\$7.2 million ${ }^{\mathrm{c}}$ & $\begin{array}{l}\text { Reestablishment (Contents) } \\
\text { Grants for damage to } \\
\text { contents }\end{array}$ & 1181 successful applications \\
\hline & AU $\$ 4.5$ million $^{\mathrm{c}}$ & $\begin{array}{l}\text { Temporary Living Expenses } \\
\text { Grants to cover essential } \\
\text { items }\end{array}$ & 1,081 successful applications \\
\hline & AU $\$ 6.3$ million $^{\mathrm{c}}$ & Personal Hardship Grants & 8311 successful applications \\
\hline
\end{tabular}

Natural Disaster Relief and Recovery Arrangements (NDRRA)

${ }^{\mathrm{a}}$ Victorian Bushfire Reconstruction and Recovery Authority (2009); ${ }^{\mathrm{b}}$ Victorian State Government (2016); ${ }^{\mathrm{c}}$ Victorian Bushfire Reconstruction and Recovery Authority (2010); ${ }^{\mathrm{d}}$ Victorian State Government (2010)

its adaptive qualities (Swiss Re 2016), and its wider currency in resilience discourses, O'Hare et al. (2016) argue that insurance is in fact maladaptive, structurally embedding risky behavior, and inhibiting adaption and resilience. Significant rates of noninsurance also undercut its effectiveness. For example, among Australian households with building (96\%) and contents insurance (71\%) (Tooth 2015), underinsurance-defined as being insured for less than $90 \%$ of recovery costs by ASIC (2014) — ranges from 27 to $81 \%$ (ASIC 2005). More recently, it was found that in a total loss scenario $83 \%$ of households' standard of living would be lowered to some degree (Quantum Market Research 2013).

Socioeconomic factors are central to exclusion from the insurance system (Tooth 2015; Booth 2018). In Australia, one in five households experience cash flow problems, and almost one in three have experienced financial stress in the last 12 months (VCOSS 2017). Research suggests that $32 \%$ of low-income earners do not have home contents insurance. Along with lower incomes, affording premiums (and excess) is difficult because households in lower socioeconomic suburbs face higher premiums due to postcodebased claims and crime risk-pricing that increase premiums (Collins 2011).

Affordability issues are amplified by insufficient market competition and a history of "inefficient" government taxes and levies (Coppel and Chester 2014; Tooth 2015). Other well-documented factors have included difficulties understanding insurance products (Enright 2013), a lack of consumer awareness of supplementary costs such as temporary accommodation and landscaping (Teague et al. 2010), cost deviations such as demand surges and changes to building regulations (Olsen and Porter 2011; Legal Aid 2014), problems calculating "sum insured" (ASIC 2014), and risk misunderstandings (Box et al. 2016). As insurance decision making is not simply based on an individual's rational calculation of potential risks, households implicitly or explicitly bring social and material concerns to bear when purchasing a policy and this can also contribute to 
Table 3 Post-disaster impacted household funding, 2010-2011 Queensland floods and Cyclone Yasi

\begin{tabular}{|c|c|c|c|c|}
\hline Payments & Funding source & $\begin{array}{l}\text { Insurance } \\
\text { considered }\end{array}$ & Payment type & Payment \\
\hline $\begin{array}{l}\text { Australian Government } \\
\text { Disaster Recovery } \\
\text { Payment }\end{array}$ & $\begin{array}{l}\text { AU\$850 million }{ }^{\mathrm{a}}- \\
\quad \text { Federal Government }\end{array}$ & No & & $\begin{array}{l}\text { AU } \$ 1000 \text { per adult; } \\
\text { AU } \$ 400 \text { per child }\end{array}$ \\
\hline \multirow{3}{*}{$\begin{array}{l}\text { Premier's Disaster Relief } \\
\text { Appeal }(\$ 205 \text { million } \\
\left.\text { with interest }{ }^{\mathrm{b}}\right)\end{array}$} & \multirow{3}{*}{$\begin{array}{l}\text { AU } \$ 22 \text { million }^{\mathrm{b}}-\text { equal } \\
\text { state and federal } \\
\text { contributions; } \\
\text { AU } \$ 250.4 \text { million } \\
\text { donations }\end{array}$} & No & $\begin{array}{l}\text { Emergency Assistance (non- } \\
\text { means tested) }\end{array}$ & $\begin{array}{l}\text { AU } \$ 2000 \text { per adult; } \\
\text { AU } \$ 1000 \text { per child }\end{array}$ \\
\hline & & $\begin{array}{l}\text { Yes, } \\
\quad(+ \text { NDRRA })\end{array}$ & $\begin{array}{l}\text { Structural Damage Assistance } \\
\text { - Destroyed Homes } \\
\text { (means-tested) }\end{array}$ & Up to AU $\$ 280,000$ per household ${ }^{b}$ \\
\hline & & $\begin{array}{l}\text { Yes } \\
\qquad(+ \text { NDRRA })\end{array}$ & $\begin{array}{l}\text { Structural Damage Assistance } \\
\text { - Damaged homes (means- } \\
\text { tested) }\end{array}$ & Up to AU $\$ 100,000$ per household ${ }^{b}$ \\
\hline \multirow{4}{*}{$\begin{array}{l}\text { Joint State and } \\
\text { Commonwealth funding } \\
\text { (NDRRA) }\end{array}$} & & No & Emergent Assistance & $\begin{array}{l}\text { AU } \$ 170 \text { per person, max. AU } \$ 850 \\
\text { per household }{ }^{\mathrm{b}}\end{array}$ \\
\hline & & Yes $^{\mathrm{b}}$ & $\begin{array}{l}\text { Household contents (means- } \\
\text { tested) }\end{array}$ & $\begin{array}{l}\text { AU } \$ 1705 \text { for individuals or } \\
\text { AU } \$ 5120 \text { for couples/families }\end{array}$ \\
\hline & & \multirow[t]{2}{*}{$\begin{array}{l}\text { Yes }(+ \text { Other } \\
\text { NDRRA) })^{\mathrm{b}}\end{array}$} & $\begin{array}{l}\text { Structural Assistance (means- } \\
\text { tested) }\end{array}$ & $\begin{array}{l}\text { AU } \$ 10,500 \text { for individuals or } \\
\text { AU } \$ 14,200 \text { for } \\
\text { couples/families }^{b}\end{array}$ \\
\hline & & & $\begin{array}{l}\text { Essential Services Safety and } \\
\text { Reconnection Grant } \\
\text { (means-tested) }\end{array}$ & $\begin{array}{l}\text { AU } \$ 4,200 \text { for repairs and AU } \$ 200 \\
\text { for each essential service per } \\
\text { household }^{\mathrm{b}}\end{array}$ \\
\hline
\end{tabular}

Natural Disaster Relief and Recovery Arrangements (NDRRA)

${ }^{\mathrm{a}}$ Coppel and Chester (2014); ${ }^{\mathrm{b}}$ Queensland Government (2011) underinsurance (Booth and Harwood 2016; Booth and Tranter 2017).

Further factors that affect the rates of under- and noninsurance are recent dramatic rises in premium costs as a result of increasing claim numbers (particularly in relation to the disasters of 2010/2011), and the progression towards risk-reflective pricing predominantly for households in flood- and cyclone-prone areas. For households at high risk of natural hazards, costly risk-reflexive premiums are not offset by national disaster insurance schemes as in other countries such as the United States (National Flood Insurance Program), New Zealand (Earthquake Commission), and the United Kingdom (FloodRe), schemes that raise issues around long-term sustainability, risk communication, and mitigation incentives (Krieger and Demerritt 2015; Worthington 2015). While some households have benefited from more accurate and granular risk calculations, for others it has raised premiums to unaffordable levels. Households in cyclone-prone areas have faced increases of up to $100 \%$ in four years and $350 \%$ for strata buildings $^{2}$ in just two years (TAGT 2015). For areas facing

\footnotetext{
2 "Strata title allows individual ownership of part of a property (called a 'lot' and generally an apartment or townhouse), combined with shared ownership in the remainder (called 'Common Property' e.g. foyers, driveways, gardens) through a legal entity called the owners corporation-or body corporate, strata company or
}

frequent flooding, premiums have risen by $41 \%$ (Smart 2014).

The catastrophic impact of Black Saturday, the Queensland's floods, and Cyclone Yasi are a sign of the future. Population growth, increasing infrastructure density, and migration to high-risk areas will invariably see an increase of such events, with projections calculating economic losses to rise to USD 29 billion in Australia by 2050 (DAE 2017). These calculations do not consider the risks posed by climate change. Traditional funding arrangements also appear unsustainable, as charitable funds will become stretched with more households affected, and donations dwindle due to charity fatigue (Latham et al. 2010). In addition, the "imperfections" of insurance described above lend support to the numerous government reports that have concluded that the only substantial and sustainable strategy for supporting current and future insurance arrangements is through investment in disaster mitigation (Coppel and Chester 2014; TAGT 2015; VCOSS 2017).

Footnote 2 continued

community association, depending on your state or territory of residence and the type of scheme" (Strata Community Association 2019). 


\section{The Case for Mitigation and Sharing Responsibilities}

At present, Australian Government funding for mitigation projects is limited to approximately USD 20 million per annum-a mere $3 \%$ of recent post-disaster spending that funds up to $50 \%$ of state and territory (hereafter "states") projects under the National Partnership Agreement on Natural Disaster Resilience (NPANDR) (Coppel and Chester 2014). In recent years, recommendations by government commissioned inquiries into disaster funding in Australia have emphasized the need for greater mitigation spending:

Governments overinvest in post-disaster reconstruction and underinvest in mitigation that would limit the impact of natural disasters in the first place. As such, natural disaster costs have become a growing, unfunded liability for governments. (Coppel and Chester 2014, p. 2, Productivity Commission Inquiry into Natural Disaster Funding Arrangements)

The Australian Business Roundtable for Disaster Resilience and Safer Communities reported that an increase of USD 185 (AU\$250) million per annum in mitigation would more than halve the estimated 2050 disaster costs (DAE 2013). This assessment supported the Productivity Commission's (Coppel and Chester 2014) call for an increase of USD 148 (AU\$200) million per annum (reducing postdisaster support to, and matched by, the states), but the recommendation was rejected due to state government funding concerns (SBS News 2016). The lack of support from states is unsurprising, given the need for Federal Government contributions to cover states' existing expenditure obligations due to insufficient revenue generation.

The Northern Australia Insurance Premiums Taskforce (TAGT 2015, p. xvi)—established to assess the feasibility of two federal funding arrangements in response to unaffordable household insurance premiums-concluded: "A sustainable way of reducing premiums over the long run is through mitigation [...] such reductions can only be achieved by household action." The Taskforce recommended investment in a range of mitigation measures, including research into more affordable retrofit options, education campaigns, and the possibility of subsidies for low-income households. When the Government's response was finally released late 2017, it stated the Federal Government would not intervene in the insurance market, acknowledging the importance of industry transparency and accountability, as well as mitigation (O'Dwyer 2017). No mention was made of the Taskforce's recommendation regarding federal financial support for household mitigation efforts.

The above inquiries represent a suite of calls for greater investment in mitigation by the Australian Government.
These center on long-term savings and strengthening of community resilience by reducing loss of life, physical injury, impacts on emotional and mental well-being, and social infrastructure (COAG 2011; DAE 2013; Coppel and Chester 2014; TAGT 2015). They highlight the less tangible impacts on individuals, households, and society that are often ignored or "priced" in order to become compatible with political discussions (DAE 2016), as well as the international disaster discourses that communicate and calculate loss in economic and physical terms (Whittle et al. 2012). A review of international cost-benefit analysis of disaster risk reduction studies shows that precedence is generally given to quantifiable economic and physical factors over environmental and social vulnerabilities (Shreve and Kelman 2014). Investing in pre-disaster mitigation measures recognizes the value of, and de-commodifies, disaster impacts on emotions, well-being, sense of security, personal and family relationships, community connections, and the meaning and values embedded within places and everyday objects (Knez et al. 2018). Unlike post-disaster approaches, greater investment in mitigation can reduce both the financial and nonfinancial risks of disasters. Despite such tangible benefits, the Australian Government's approach to disaster funding remains stagnant.

Despite the Australian Government accepting the inevitability of a changing climate (while still grappling with the extent of human activity contributions), it remains firmly cemented in practices that favor post-disaster spending. A reactive funding structure that responds to actual rather than projected costs has the potential to lower opportunity and administration expenses. However, this approach limits incentives to invest in mitigation, heightens risks of fiscal volatility and obscures funding transparency (Coppel and Chester 2014). A reactive approach keeps disaster funding off the budget, which assists the balancing of books, but makes policy change difficult (McGowan 2012). Consequently, disaster relief can be a significant and largely uncontrolled part of the federal budget, and state governments under the Natural Disaster Relief and Recovery Arrangements (NDRRA) lack financial encouragement to take greater mitigative steps, including insurance (National Commission of Audit 2014). In contrast to this unquantified, legally nonbinding, disaster-contingent liability approach to government spending, investing in mitigation measures "is an upfront cost that is subject to trade-offs with other policy priorities as well as the scrutiny that applies to the budgeting process" (Coppel and Chester 2014, p. 360). Federal and state government partiality towards post-disaster spending can also be attributed to "political opportunism and short-sightedness" that result in reactive "policy on the run," and inequitable and unsustainable outcomes from seemingly 
generous political acts during disasters (COAG 2011; Coppel and Chester 2014, pp. 13, 4).

While the fiscal approach of the Australian Government remains skewed to post-disaster recovery, discourses and practices of disaster management in Australia have shifted from an agency-managed approach to one that acknowledges the importance of community members in developing resilience (Coppel and Chester 2014). This shift to "risk sharing" and "responsibilization" reflects international trends that recognize the social, technical, economic, environmental, and political priorities in mitigating disaster impacts (McLennan and Handmer 2014). In Australia, the concept of risk sharing is still in its infancy, as "the Shared Responsibility discourse is articulating a new social contract for disaster management but half of the contract terms are missing" (McLennan and Handmer 2014, p. 6).

Guidance for shared responsibility in the National Strategy for Disaster Resilience (COAG 2011, p. 2) emphasizes that "communities, individuals and households need to take greater responsibility for their own safety and act on information, advice and other cues provided before, during and after a disaster." However, the Victorian Bushfires Royal Commission (Teague et al. 2010, p. 6) argued that shared responsibility does not mean equal responsibility, as State knowledge and resources means the State, rather than households, is better placed to identify and mitigate risk. The Commission suggested the State should take a greater share of responsibility, for example, through greater information provisions and risk management, which is to be understood and acted on by households.

While households, along with all three tiers of government and some private sectors (such as energy providers), are highlighted in discussions on shared responsibility, the insurance sector has flown under the radar. This is partly due to the private commercial status of the industry. Recommendations directed at the insurance sector and its responsibility in risk reduction have been superficial, underscoring the need for greater regulation around its selfregulated code of practice in order to increase transparency and accountability, and encourage more flexible products (Holmes 2012; TAGT 2015). The limited integration of insurers into the shared responsibility discourse can be explained by the maladaptive operational logics of the insurance sector. For example, in the aftermath of the 2013 Blue Mountains bushfires in New South Wales, 65\% of residents found themselves underinsured largely due to a lack of knowledge on changes to Bushfire Attack Level $(B A L)^{3}$ zoning (Legal Aid 2014). While insurers had

\footnotetext{
3 A Bushfire Attack Level (BAL) is a means of measuring the severity of a building's potential exposure to ember attack, radiant heat, and direct flame contact. The greater the distance from the fire the lower the heat flux, and therefore the construction standard is lower.
}

knowledge of these changes and were called out (along with local Councils) by residents and politicians, the Insurance Council of Australia stated that it is "primarily the responsibility of governments to explain to constituents the consequences of changes to laws or regulations that they enact" (Madigan 2016). Insurers appear keen to retain a focus on government responsibility, which limits their own responsibilities and the risks associated with meeting (or not meeting) these responsibilities.

There have been calls for the insurance industry to do more, albeit for financial gain (EY 2014). Hawker (2007, p. 24) describes the insurance industry as "a 'barometer' of climate change impacts on society." This places insurers in a unique advisory position for policymakers, communities, and other business sectors, with a role in cross-sectoral and multistakeholder action. Insurers can also support greater insurance uptake by improving insurance equitability, discounts for mitigation measures, and through trustfactors that contribute to underinsurance (Collins 2013; O'Dwyer 2017; State Government of Victoria 2017; Senate Economics References Committee 2017). This also includes transparency in risk rating, where disaster risk is currently bundled and often cross-subsidized with other everyday risks, such as burglary and housefire (O'Hare et al. 2016).

Insurers could be more proactive in encouraging households to manage disaster risks. In the aftermath of the Queensland floods there were few accounts of insurers reducing premiums, or providing insurance coverage where there previously was none (Bird et al. 2013). However, some insurers are beginning to recognize household efforts. Since 2016, two insurers-Suncorp (2016) and RACQ (2016) - have offered premium discounts for cyclone mitigation measures. While Suncorp does not disclose which measures are recognized, RACQ (2016) offers up to $20 \%$ off the cyclone component of household premiums for measures such as roof security, open protection, roof replacement, and house retrofits that meet current building codes. Such options are not available for other disaster types.

The insurance industry could also contribute to household resilience by, for example, running awareness campaigns on the importance of property preparedness, utilizing post-disaster repairs as an opportunity to increase resilience among existing building stock (Bell 2011), greater involvement in building standards and urban planning (Booth 2018), funding contributions to public education on risk exposure (Carter 2012), national data collection, research and analysis on disaster assessments (Matthews et al. 2002), and working with governments and disaster management agencies on hazard identification and risk assessment (King et al. 2013; Coppel and Chester 2014). 
Ultimately, the lack of accountability from the insurance industry in promoting long-term disaster mitigation measures comes down to conflicting business models:

Ambitions of insurance as a mode of resilience are overwhelmingly stability orientated, rebounding to a preshock "normality" where risk is absorbed by a system, but rarely avoided or reduced. In particular, fundamental principles of insurance, such as risk transfer and moral hazard, along with operational norms including risk pooling and betterment, limit the extent to which adaptive behaviour can occur. (O'Hare et al. 2016, p. 1185)

As disasters become more frequent and costlier, it seems in the best interest of households, governments, and insurers alike to take responsibility for risk mitigation whenever possible. The long-term sustainability of both insurance and government sectors arguably rests on principles of risk adaptation and shared responsibility rather than stability and restoration to a normality that seems to no longer exist.

\section{Securing Resilience}

There appears to be a sound argument for increased funding for mitigation and the sharing of responsibility across governments, households, and insurers. However, important questions remain relating to mitigation as constituted by a broad array of protection, preparedness, and resilience initiatives, ranging from traditional flood prevention levees, to the retrofitting of houses. On the one hand, conventional protection measures, such as flood levees, align with long-standing maladaptive insurance logics, promising to enhance insurability through a reduction in the risk of flooding. On the other hand, mitigation measures designed to enhance community and household resilience, such as retrofitting, face considerable barriers from an insurance industry that is both unwilling to invest in pre-disaster preparedness (thus the burden of financial responsibility falls on individual householders), and is largely unwilling and/or unable to price resilience in premiums. We explore this in a critical examination of existing and proposed mitigation projects in Australia, along with mitigation recommendations outlined in government reports and relevant academic literature.

\subsection{Floods: Hard Mitigation Measures}

Proactive state government responses to flood impacts has resulted in education campaigns encouraging households to better protect themselves through property retrofits, maintenance and preparation, emergency response plans, and building and utilizing social connections (Queensland Government 2017). Yet for some households, the capacity to reduce disaster risk is beyond their control. Government investment in hard mitigation measures can instead alleviate vulnerabilities. In 2011 and again in 2012, for example, up to 444 houses were inundated by flood waters in Roma, Queensland. As a result, a USD 12 million flood mitigation project, stage one of the Roma levee, was completed three years later, protecting 483 houses from 1-in-100 floods (Urbis 2014). Along with the 4.9 costbenefit ${ }^{4}$ calculated over 50 years, a ratio comparable to flood risk reduction activities internationally (Shreve and Kelman 2014), the levee's construction has reopened household access to previously denied insurance coverage, while reducing premiums for around 1400 households by $30 \%$, or as much as $80 \%$ for high-risk households (Coppel and Chester 2014; Urbis 2014). The levee stands to substantially reduce both the broader community's collective trauma and the physical, mental, and emotional strain households endure during and after disasters to maintain or rebuild the physical fabric and feel of their homes and their everyday lives (Whittle et al. 2012; Dixon et al. 2015). However, we note the residual risk implications in the context of climate change increases for flood probabilities.

Greater financial commitment by governments to flood mitigation would likely see an increase in similar hard mitigation measures, including the long-awaited South Rockhampton Flood Levee in Queensland. The leveeproposed 25 years ago-would provide flood protection to 1000 homes that have recurrently been isolated by floods for weeks rather than days. During the 2010-2011 floods, households lost water and electricity supplies, were placed at risk by compromised sewerage systems, and lost access to homes, schools, and businesses due to 179 road closures. In an area with high levels of socioeconomic disadvantage, many households were "financially destroyed" and insurance remains a barrier to resilience due to unavailable or high insurance premiums (Rockhampton Regional Council 2013, p. 12). The proposed levee would offset the USD 30 million cost of raising the Bruce Highway, which is flooded during 1-in-10-year floods, severing road access to central and north Queensland and costing USD 60 million in State economic losses in 2011 alone. Despite the USD 50 million recently spent by all three tiers of government on flood repairs over four years, the South Rockhampton Flood Levee project has remained unfunded given the USD 37-44 million price tag (Rockhampton Regional Council 2013; Strelow and Holmes 2015). Funding the project

\footnotetext{
${ }^{4}$ Cost-benefit calculates the tangible and intangible financial benefits as a return on the initial financial layout. The higher the ratio, the better the investment. A cost-benefit of 1.0 represents a full financial return, with higher numbers representing additional savings-a 2.0 cost-benefit, for example, represents a twofold return.
} 
would provide households with protection from regular flooding and access to affordable insurance coverage. It would intercept current disaster and insurance mechanisms that are socially and financially marginalizing many households.

Combined with the variegated patterns of noninsurance, disasters often entrench place-based disadvantage (O'Hare et al. 2016; Booth 2018). Many socioeconomically disadvantaged communities are located in disaster-prone areas across Australia. The capacity of these households to reduce risk is often beyond their control, as no feasible level of household retrofitting or property maintenance could notably reduce flood impacts. Only government funded mitigation measures can sustainably lower their physical risk and reopen access to insurance systems (Coppel and Chester 2014; DAE 2017). While the benefit from such hard mitigation measures are directly felt by households initially, in time these measures would benefit society more broadly, as fewer high-risk households enter insurance pools, reducing premiums (assuming savings are passed on to consumers).

\subsection{Cyclones-Subsidization of House Infrastructure}

Key to reducing cyclone impacts is property retrofits. The importance of improving building strength is evident from post-1980s building stock constructed in accordance with stringent wind-loading requirements. During Cyclone Yasi, only $3 \%$ of post- 1980 buildings sustained damage, compared with $12 \%$ of buildings built pre-1980 (King et al. 2013). For this reason, responsibility for mitigation measures has fallen to households. But retrofit options are not cheap. The cost to strengthen roofs, doors, and windowsbuilding features most commonly damaged in cyclones-is estimated between USD 8361 and USD 40,370 per house, with variations dependent on retrofit aesthetics and permanency. Urbis (2015) calculated the cost-benefit ratios for different retrofits, varying between 1.1 (over-batten roofing over a 5-year period) to 12.9 (roof strapping over a 4-year period). In addition to longer-term financial savings (and increased property values), retrofits should reduce current unsustainable household insurance premiums. As with flooding, this approach should also result in further discounts for insured households due to reductions in insurance claims (TAGT 2015). While the argument for household mitigation is financially sound, the outlay required by households is in many cases prohibitive.

Unlike flood or bushfire impacts, the force of wind cannot be mitigated through hard measures (with the exception of reducing debris). Consequently, managing cyclones attracts little financial support beyond education campaigns and emergency response. At risk households are therefore disadvantaged compared with households facing floods and bushfires. The previously disregarded TAGT (2015) recommendation for household mitigation subsidies, and research funding for more cost-effective and aesthetic retrofits, could alleviate the financial burden, particularly for lower-income households. It would allow more households greater physical protection and access to more affordable insurance. The TAGT (2015) recommendation for education campaigns, designed to "improve cyclone preparedness could be the most effective way to reduce the number of minor claims" (Urbis 2015, p. 8). Minor claims after Cyclone Yasi accounted for $86 \%$ of claims and $29 \%$ of insured losses. Research estimates the proposed education program would save households on average USD 225-566 in damages, offsetting program costs with a 3.2-14.9 cost-benefit, and reducing reliance on insurance systems (DAE 2017). Together, mitigation subsidization, research, and education campaigns could contribute to a more equitable and stable insurance system, as well as a reduction in debris, collateral damage, and demands on emergency services (TAGT 2015).

\subsection{Bushfires-Retrofitting Properties}

Current bushfire mitigation measures are well-rounded and established, with emphasis on community engagement, development restrictions, building regulations, hazard reduction strategies, and emergency response. Such strategies are reflected in the Victorian State Government's (2011) response to the 2009 Victorian Bushfires Royal Commission's (Teague et al. 2010) recommendations, over a quarter of which directly support households in preparation and response. However, the Commission's recommendations for fireproof landscaping and safety measures for existing buildings did not consider the financial and time costs required from households.

Current estimates for property preparations range between USD 6600 and USD 34,800 (averaging USD 18,200) (Penman et al. 2017), with an average of USD 7400 for initial outlays and USD 740 per annum for maintenance costs (Penman et al. 2016). While a wellprepared home increases the likelihood of a property surviving a bushfire, the above studies found that the financial and labor costs of preparations and/or retrofits are beyond what many households are willing or able to pay. Penman et al. $(2016,2017)$ suggest that for households who accept responsibility for their own risk, a shared-investment property mitigation scheme and case-specific information could positively improve household resilience. The latter is important, given that many residents struggle to apply generic bushfire advice to their property (Penman et al. 2017). 
Supporting households to undertake property improvements will become more important in future insurance contexts. Unlike floods and cyclones, risk-pricing for bushfires is only now beginning to be calculated in insurance premiums, as bushfires have previously been considered a negligible risk (King et al. 2013). This change is likely the result of insurance administrative costs, population growth, and asset increase in high-risk areas, the rising frequency and intensity of high-fire-danger-days, improvements in risk mapping, and the capacity of insurers to encourage households to take responsibility for their own risk (Teague et al. 2010; Booth and Tranter 2017). As with cyclones, financial support for household retrofits are envisaged to counter future insurance increases, contribute to greater community resilience by reducing fire risk in adjoining areas, and assist the sustainability of insurance systems by limiting future claims. More broadly, mitigation measures can reduce the traumatic experiences of survivors and firefighters and the associated short- and long-term consequences (Caruana 2010; Eriksen 2014).

\subsection{Current Barriers to Household Mitigation Measures}

In line with shared-responsibility frameworks, households are being encouraged to become more self-sufficient and accept greater responsibility for their risk management. However, expectations around household contributions and how these actions can be communicated are commonly based on standard assumptions about household capacities and behaviors. Most strategies assume households have the physical and mental capacity to understand and implement mitigation measures. However, in many instances, this is not the case (Eriksen 2014; Sword-Daniels et al. 2018). Older people in remote areas of Australia, for example, have been found at higher risk of cyclone impacts due to their physical inability to clear gutters and a lack of social support (Astill and Miller 2016). Australian programs, such as AIDER (Assist Infirm, Disabled and Elderly Residents), provide services that support at risk communities, but resources and geography provide significant barriers to outreach.

Strategies for reducing risk, including adequate insurance, are also built around the assumption that households will act as rational agents. They assume that households have the time and financial capacity to implement and maintain measures, understand and accept the hazards and risks they face, and appreciate the long-term value of mitigation investments (Craik et al. 2012; Penman et al. 2016). They also assume that higher-income households are more likely to invest in mitigation due to the availability of funds. In reality, there are few points of traction within the life cycle of a house where substantial changes to a property are made, such as property purchase, rebuild, and insurance purchase and renewal (O'Connell et al. 2015). This is particularly true for landlords who have legal restrictions pertaining to property access, as do tenants with regard to the implementation of measures (Bird et al. 2013; O'Hare et al. 2016).

Barriers to greater mitigation investment that influence decision making at all levels of government permeate through to decisions at the household level. Barriers, regardless of the level at which they operate, will need to be addressed if strategies are to be successful, and to avoid further disadvantaging marginalized groups.

\section{Conclusion}

Building on growing demand for greater government investment in disaster mitigation, this article has examined how an increase in mitigation funding might affect household insurance access and affordability. In focusing on the household, we want to conclude by making four points. First, our review underscores that, unlike post-disaster response and recovery, investment in mitigation measures works to intercept and lessen the potential impact before damage is done. The impacts of disasters are more than numerical figures or quantified outcomes used to gain currency in political decision making. For households, the impact can be physically and emotionally traumatic through damage to, or erasure of, local environments and livelihoods, social relations, and daily routines, which aid everyday meaning-making and a sense of security. These impacts are felt and endured by households in ways that cannot be measured by the associated socioeconomic costs of family breakdowns, health implications, or the loss of individuals' sense of belonging and self-worth.

Second, as the analysis of mitigation makes clear, security logics are strongly shaped by the configurations of different disaster types. Cyclones, for example, exceed endeavors to govern through logics of protection, in contrast to the continued hold that protection logics have on flood mitigation efforts. Each disaster type requires tailored mitigation approaches that respond to disaster-specific impacts and gaps in current disaster reduction efforts. In the examples provided in this article, mitigation projects have reduced the frequency of property flooding, community isolation, and restricted access to water, electricity, and sewerage systems. They can provide financial support for housing retrofits that reduce building vulnerability, providing households with a more secure space to shelter.

In turn, the different logics of mitigation at work for different disaster types shape the politics of household responsibilization. Under the shared-responsibility 
framework, households exposed to cyclone risks are left with the responsibility of building resilience, as the impact of wind and rain on properties cannot be diminished by measures on public land, such as through flood levees or firebreaks. While governments could financially support households to better prepare their properties through subsidization and investment in research for more financially and aesthetically appealing mitigation measures, they instead avoid investment in measures that yield little shortterm political gain, as such measures lack the grandeur of hard infrastructural projects. The lack of current government assistance for these households raises questions around equity in government financial support for mitigation between disaster types, especially given that the government has recently ignored TAGT recommendations. More research is required that considers the severity of impacts and levels of need between different disaster types, as well as the differences in state and federal policies and regulations. The transition to a pre-disaster mitigation mode of security is likely to do little to alleviate disadvantage and marginalization for householders in cycloneand bushfire- prone areas who lack the capacities to prepare themselves and their properties, as the insurance industry remains largely maladaptive in its operational logics and does not marketize resourcefulness (Cooper 2015).

Fourth, in the case of all three disaster types examined in this article, the implementation of mitigation measures would likely improve insurance affordability and provide insurance options where they had previously been unavailable. Such outcomes are likely to partly reduce cycles of social and financial marginalization, particularly in areas exposed to recurrent disasters. However, while a reduction in household exposure to disaster risks through mitigation could make a significant difference to equitable access and adequate levels of home and contents insurance - a key goal of the National Strategy for Disaster Resilience (COAG 2011) - the impact on insurability will be determined by the specific logics of mitigation. Protective mitigation initiatives such as flood levees work within existing maladaptive insurance frameworks and have the potential to reduce risk and premiums, and thus increase access to insurance for the economically deprived and those living in high-risk areas. However, such potential benefits must be set against the significant political and fiscal constraints that neoliberal governance places on large-scale preventive projects, and the deepening individualization of risk-reflective pricing, which limits insurance cross-subsidization. Future premiums for Bushfire Attack Level (BAL) zoning, for example, are likely to be based on risk-reflective pricing.

Conversely, the implementation of mitigation measures based on the logics of preparedness and resilience to improve affordability and access requires a paradigm shift in the operational and security logics of insurers. Insurers have to be willing and able to price household mitigation measures. While arguments have been made that such expectations are beyond insurer capacity and responsibility (TAGT 2015), our article points to the precedence set by Suncorp and RACQ. For households who remain excluded from insurance markets, and who are unable to implement measures of their own, there are secondary benefits to mitigation investment in the form of reduced risk posed from surrounding properties, lessened impacts to community connectedness, and lowered demand on emergency services.

Acknowledgements This research was funded by the Australian Research Council (DP170100096).

Open Access This article is distributed under the terms of the Creative Commons Attribution 4.0 International License (http://crea tivecommons.org/licenses/by/4.0/), which permits unrestricted use, distribution, and reproduction in any medium, provided you give appropriate credit to the original author(s) and the source, provide a link to the Creative Commons license, and indicate if changes were made.

\section{References}

Aon Benfield. 2018. Weather, climate and catastrophe insight, 2017 annual report. Aon Benfield. http://www.aon.com.au/australia/ insights/articles/2018/2017-costliest-year-on-record-forweather-disasters.jsp. Accessed 1 Oct 2018.

Aradau, C. 2014. The promise of security: Resilience, surprise and epistemic politics. Resilience 2(2): 73-87.

ASIC (Australian Securities and Investments Commission). 2005. Getting home insurance right: A report on home building underinsurance. https://asic.gov.au/regulatory-resources/find-adocument/reports/rep-54-getting-home-insurance-right-asicsreport-on-home-building-underinsurance/. Accessed 18 Mar 2019.

ASIC (Australian Securities and Investments Commission). 2014. Review of the sale of home insurance. https://asic.gov.au/ regulatory-resources/find-a-document/reports/rep-415-reviewof-the-sale-of-home-insurance/. Accessed 18 Mar 2019.

Astill, S., and E. Miller. 2016. The trauma of the cyclone has changed us forever: Self-reliance, vulnerability and resilience among older Australians in cyclone-prone areas. Ageing \& Society 38(2): 403-429.

Bell, J. 2011. Insurance for extreme weather events in Australiacurrent policy trends, and future directions. Macquarie Journal of Business Law 8: 339-357.

Bird, D.K., D. King, K. Haynes, P. Box, T. Okada, and K. Nairn. 2013. Impact of the 2010-2011 floods and the factors that inhibit and enable household adaptation strategies. Gold Coast, Queensland: National Climate Change Adaptation Research Facility. https://www.nccarf.edu.au/sites/default/files/attached_ files_publications/Bird_2013_Floods_household_adaptation_stra tegies.pdf. Accessed 27 Jun 2018.

Booth, K. 2018. Profiteering from disaster: Why planners need to be paying more attention to insurance. Planning Practice \& Research 33(2): 211-227. 
Booth, K., and A. Harwood. 2016. Insurance as catastrophe: A geography of house and contents insurance in bushfire-prone places. Geoforum 69: 44-52.

Booth, K., and B. Tranter. 2017.When disaster strikes: Underinsurance in Australian households. Urban Studies 55(14): $3135-3150$.

Booth, K., and S. Williams. 2012. Is insurance an under-utilised mechanism in climate change adaptation? The case of bushfire management in Tasmania. Australian Journal of Emergency Management 27(4): 38-45.

Box, P., D. Bird, K. Haynes, and D. King. 2016. Shared responsibility and social vulnerability in the 2011 Brisbane flood. Natural Hazards 81(3): 1549-1568.

Carter, R.A. 2012. Flood risk, insurance and emergency management in Australia. Australian Journal of Emergency Management 27(2): 20-25.

Caruana, C. 2010. Picking up the pieces: Family functioning in the aftermath of natural disaster. Family Matters No. 84: 79-88.

Chandler, D., and J. Coaffee. 2016. The Routledge handbook of international resilience. London: Routledge.

Cigler, B.A. 2017. U.S. floods: The necessity of mitigation. State and Local Government Review 49(2): 127-139.

COAG (Council of Australian Governments). 2011. National strategy for disaster resilience. Canberra: Australian Government. https:// knowledge.aidr.org.au/media/2153/nationalstrategyfordisasterre silience.pdf. Accessed 18 Mar 2019.

Collins, D. 2011. Reducing the risks: Improving access to home contents and vehicle insurance for low-income Australians. Fitzroy, Victoria: Brotherhood of St Laurence. https://www.bsl. org.au/research/browse-publications/reducing-the-risks-improv ing-access-to-home-contents-and-vehicle-insurance-for-lowincome-australians/. Accessed 18 Mar 2019.

Collins, D. 2013. Covering the essentials: Increasing access and affordability of insurance for people on low incomes. Northcote: Good Shepard Microfinance. https://goodshepherdmicrofinance. org.au/assets/files/2016/06/The-Essentials.pdf. Accessed 18 Mar 2019.

Cooper, M. 2015. Resilience and uninsured risk. Resilience: International Policies, Practices and Discourses 3(2): 133-136.

Coppel, J., and K. Chester. 2014. Natural disaster funding arrangements: Productivity commission inquiry report. Canberra: Productivity Commission. https://www.pc.gov.au/inquiries/ completed/disaster-funding/report. Accessed 18 Mar 2019.

Craik, W., J. Coppel, and N. Byron. 2012. Barriers to effective climate change adaptation: Productivity commission inquiry report. Canberra: Productivity Commission. https://www.pc.gov. au/inquiries/completed/climate-change-adaptation/report/cli mate-change-adaptation.pdf. Accessed 18 Mar 2019.

DAE (Deloitte Access Economics). 2013. Building our nation's resilience to natural disasters. Canberra: DAE. http://australian businessroundtable.com.au/our-research. Accessed 18 Mar 2019.

DAE (Deloitte Access Economics). 2016. The economic cost of the social impact of natural disasters. Canberra: DAE. http:// australianbusinessroundtable.com.au/our-research. Accessed 30 May 2018.

DAE (Deloitte Access Economics). 2017. Building resilience to natural disasters in our states and territories. Canberra: DEA. http://australianbusinessroundtable.com.au/our-research. Accessed 18 Mar 2019.

Dixon, K.M., I.M. Shochet, and J. Shakespeare-Finch. 2015. Stress during the rebuilding phase influenced mental health following two Queensland flood disasters more than the event itself. In Proceedings of the Australian and New Zealand Disaster and Emergency Management Conference, 3-5 May 2015, 1-13. Broadbeach, Queensland. https://eprints.qut.edu.au/84338/18/
ANZDMC\%20paper\%20accepted\%20version.pdf. Accessed 18 Mar 2019.

Edwards, C., and C. Davis. 2012. Lloyd's global underinsurance report. London: Society of Lloyd's. https://www.lloyds.com/ news-and-risk-insight/risk-reports/library/understanding-risk/glo bal-underinsurance-report. Accessed 18 Mar 2019.

Enright, I. 2013. General insurance code of practice independent review 2012-2013 final report. https://www.insurancecouncil. com.au/for-consumers/code-of-practice/2012-review. Accessed 18 Mar 2019.

Eriksen, C. 2014. Gender and wildfire: Landscapes of uncertainty. New York: Routledge.

Evans, B., and J. Reid. 2014. Resilient life: The art of living dangerously. Cambridge: Polity Press.

EY (Ernst \& Young). 2014. Reimagining customer relationships: Key findings from the EY global consumer insurance survey 2014. New York: EY. https://www.ey.com/Publication/vwLUAssets/ ey-2014-global-customer-insurance-survey/\$FILE/ey-global-cus tomer-insurance-survey.pdf. Accessed 18 Mar 2019.

Hawker, M. 2007. Climate change and the global insurance industry. Geneva Papers on Risk and Insurance - Issues and Practice 32(1): 22-28.

Holmes, C.E. 2012. Queensland floods commission of inquiry: Final report. Brisbane: Queensland Floods Commission of Inquiry. http://www.floodcommission.qld.gov.au/_data/assets/pdf_file/ 0007/11698/QFCI-Final-Report-March-2012.pdf. Accessed 18 Mar 2019.

Jon, I. 2018. Resilience and 'technicity': Challenges and opportunities for new knowledge practices in disaster planning. Resilience: International Policies, Practices and Discourses. https://doi.org/ 10.1080/21693293.2018.1461481. Accessed 18 Mar 2019..

Kellett, J., and A. Caravani. 2013. Financing disaster risk reduction: A 20 year story of international aid. London: Overseas Development Institute and Global Facility for Disaster Reduction and Recovery. https://www.odi.org/publications/7452-financing-dis aster-risk-reduction-20-year-story-international-aid. Accessed 18 Mar 2019.

King, D.C., J. Ginger, S. Williams, A. Cottrell, Y. Gurtner, C. Leitch, D. Henderson, N. Jayasinghe, et al. 2013. Planning, building and insuring: Adaptation of built environment to climate change induced increased intensity of natural hazards. Gold Coast, Queensland: National Climate Change Adaptation Research Facility. https://www.nccarf.edu.au/synthesis/planning-buildingand-insuring-adaptation-built-environment-climate-changeinduced. Accessed 18 Mar 2019.

Knez, I., A. Butler, Å. Ode Sang, E. Ångman, I. Sarlöv-Herlin, and A. Åkerskog. 2018. Before and after a natural disaster: Disruption in emotion component of place-identity and wellbeing. Journal of Environmental Psychology 55: 11-17.

Krieger, K., and D. Demeritt. 2015. Limits of insurance as risk governance: Market failures and disaster politics in German and British private flood insurance. London: Centre for Analysis of Risk and Regulation, London School of Economics and Political Science. http://www.lse.ac.uk/accounting/CARR/pdf/DPs/DPKrieger-Demeritt.pdf. Accessed 18 Mar 2019.

Latham, C., P. McCourt, and C. Larkin. 2010. Natural disasters in Australia: Issues of funding and insurance. In Proceedings of the Institute of Actuaries of Australia 17th General Insurance Seminar, 7-10 November 2010, 1-29. Gold Coast, Queensland. https://actuaries.asn.au/library/events/GIS/2010/NaturalDisaster sInAustralia-Paper.pdf. Accessed 18 Mar 2019.

Legal Aid. 2014. Response to issues paper on natural disaster funding arrangements. https://www.legalaid.nsw.gov.au/_data/assets/ pdf_file/0003/19722/Submission-Natural-Disaster-FundingArrangements-June-2014-final.pdf. Accessed 18 Mar 2019. 
Madigan, D. 2016. Mark Dreyfus sparks war of words with insurance industry over Blue Mountains bushfires. The Blue Mountains Gazette, 21 April 2016. https://www.bluemountainsgazette.com. $\mathrm{au} /$ story/3863519/dreyfus-sparks-war-of-words-with-insuranceindustry-over-blue-mountains-bushfires/. Accessed $25 \mathrm{Sept}$ 2018.

Matthews, K., R. Mitchell, M. Castle, B. Howard, B. Apsey, D. Pepper, P. Bickerstaff, S. Carman, et al. 2002. Natural disasters in Australia: Reforming mitigation, relief and recovery arrangements. Canberra: Council of Australian Governments.

McGowan, J. 2012. A missed opportunity to promote community resilience?-The Queensland Floods Commission of Inquiry. Australian Journal of Public Administration 71(3): 355-363.

McLennan, B., and J. Handmer. 2014. Sharing responsibility in Australian disaster management: Final report for the sharing responsibility project. East Melbourne, Victoria: Bushfire Cooperative Research Centre. http://www.bushfirecrc.com/publica tions/citation/bf-4290. Accessed 18 Mar 2019.

National Commission of Audit. 2014. Towards responsible government. Canberra: Commonwealth of Australia. https://www.ncoa. gov.au/. Accessed 14 Feb 2018.

O'Connell, D., B. Lin, T. Capon, and M.S. Smith. 2015. Disaster resilience and mitigation: A short report on current and future capacity to deliver on risk assessment and mitigation needs. Australia: CSIRO (Commonwealth Scientific and Industrial Research Organisation). https://publications.csiro.au/rpr/pub? pid=csiro:EP156099. Accessed 18 Mar 2019.

O'Dwyer, K. 2017. Government responds to Northern Australia Insurance Premiums Taskforce and General Insurance Senate Inquiry. http://kmo.ministers.treasury.gov.au/media-release/1202017/. Accessed 18 Mar 2019.

O'Hare, P., I. White, and A. Connelly. 2016. Insurance as maladaptation: Resilience and the 'business as usual' paradox. Environment and Planning C: Government and Policy 34(6): $1175-1193$.

Olsen, A.H., and K.A. Porter. 2011. What we know about demand surge: Brief summary. Natural Hazards Review 12(2): 62-71.

Penman, T.D., C. Eriksen, B. Horsey, and R.A. Bradstock. 2016. How much does it cost residents to prepare their property for wildfire? International Journal of Disaster Risk Reduction 16: 88-98.

Penman, T.D., C. Eriksen, B. Horsey, A. Green, D. Lemcke, P.Cooper, and R.A. Bradstock. 2017. Retrofitting for wildfire resilience: What is the cost? International Journal of Disaster Risk Reduction 21: 1-10.

Quantum Market Research. 2013. The understand insurance research report. Melbourne: Insurance Council of Australia. http://under standinsurance.com.au/assets/pdf/FINAL\%20Understand\% 20Insurance\%20Research\%20Report.pdf. Accessed 19 Feb 2019.

Queensland Cabinet and Ministerial Directory. 2011. Yasi damage bill set to top $\$ 800$ million. http://statements.qld.gov.au/state ment/id/73637. Accessed 8 Mar 2018.

Queensland Government. 2011. Premier's disaster relief appeal. http://www.parliament.qld.gov.au/Documents/TableOffice/Table dPapers/2011/5311T5563.pdf. Accessed 3 Mar 2018.

Queensland Government. 2017. Get ready Queensland. https:// getready.qld.gov.au. Accessed 4 Sep 2018.

RACQ (Royal Automobile Club of Queensland). 2016. Cyclone mitigation discount. https://www.racq.com.au/insurance/learnmore-about-insurance/be-prepared/storms-and-cyclones/ cyclone-mitigation/cyclone-mitigation-terms-and-conditions. Accessed 18 Mar 2019.

Rockhampton Regional Council. 2013. Protecting Rockhampton's future: A case for a flood levee. https://www.rockhamptonregion. qld.gov.au/files/assets/public/regional-services/disaster-manage ment/marketing/flood_levee_proposal.pdf. Accessed 2 Jan 2018.
SBS News. 2016. Government says no to $\$ 200 \mathrm{~m}$ disaster mitigation fund. Australian Associated Press, 22 December 2016. https:// www.sbs.com.au/news/government-says-no-to-200m-disastermitigation-fund. Accessed 18 Mar 2019.

Senate Economics References Committee. 2017. Australia's general insurance industry: sapping consumers of the will to compare. Canberra: Commonwealth of Australia. https://www.aph.gov.au/ Parliamentary_Business/Committees/Senate/Economics/General insurance/Report. Accessed 18 Mar 2019.

Shreve, C.M., and I. Kelman. 2014. Does mitigation save? Reviewing cost-benefit analyses of disaster risk reduction. International Journal of Disaster Risk Reduction 10: 213-235.

Smart, J. 2014. The role of post-disaster institutions in recovery and resilience: A comparative study of three recent disasters. In Future-proofing the state, ed. J. Boston, J. Wanna, V. Lipski, and J. Pritchard, 229-250. Canberra: ANU (Australian National University) Press.

State Government of Victoria. 2017. Addressing non-insurance and underinsurance for emergencies in Victoria: Discussion paper. Melbourne: Department of Health and Human Services. https:// vcoss.org.au/wp-content/uploads/ 2017/05/Insurance-Discus sion-Paper-final-130417.pdf. Accessed 18 Mar 2019.

Strata Community Association. 2019. What is strata? https://www. strata.community/understandingstrata/what-is-strata. Accessed 18 Mar 2019.

Strelow, M., and B. Holmes. 2015. It is hard to love a levee. In Proceedings of the Floodplain Management Association National Conference, 19-22 May 2015, 1-12, Brisbane, Australia. https://www.floodplainconference.com/papers2015/Mar garet\%20Strelow\%20F.pdf. Accessed 2 Jan 2018.

Suncorp. 2016. Cyclone resilience benefit. https://www.suncorp.com. $\mathrm{au} / \mathrm{insurance/safety/cyclone-resilience.html}$. Accessed $18 \mathrm{Mar}$ 2019.

Swiss Re (Swiss Reinsurance Company). 2016. World insurance in 2015: Steady growth and regional disparities. Zurich: Swiss Re.

Sword-Daniels, V., C. Eriksen, E.E. Hudson-Doyle, R. Alaniz, C. Adler, T. Schenk, and S. Vallance. 2018. Embodied uncertainty: Living with complexity and natural hazards. Journal of Risk Research 21(3): 290-307.

TAGT (The Australian Government Treasury). 2015. Northern Australia Insurance Premiums Taskforce, Final report. Canberra: TAGT. https://treasury.gov.au/publication/northern-austra lia-insurance-premiums-taskforce-final-report/. Accessed $18 \mathrm{Mar}$ 2019.

Teague, B., R. McLeod, and S. Pascoe. 2010. 2009 Victorian Bushfires Royal Commission final report. Melbourne: Government Printer for the State of Victoria. http://royalcommission. vic.gov.au/Commission-Reports/Final-Report.html. Accessed 18 Mar 2019.

Tooth, R. 2015. Analysis of demand for home and contents insurance. Australia: Sapere Research Group. http://www.insurancecouncil. com.au/issue-submissions/reports/analysis-of-demand-for-homeand-contents-insurance-by-dr-tooth. Accessed 18 Mar 2019.

Trowbridge, J., J. Minto, and J. Berrill. 2011. National disaster insurance review: Inquiry into flood insurance and related matters. Canberra: The Australian Government Treasury.

UNISDR (United Nations International Strategy for Disaster Reduction). 2016. Report of the open-ended intergovernmental expert working group on indicators and terminology relating to disaster risk reduction. Geneva: UNISDR. https://www.preventionweb. net/files/50683_oiewgreportenglish.pdf. Accessed 16 May 2018.

Urbis. 2014. Economic benefits of flood mitigation investments. Brisbane: Urbis. https://www.pc.gov.au/inquiries/completed/dis aster-funding/submissions/submissions-test $2 /$ submission-coun ter/subdr176-disaster-funding-attachment.pdf. Accessed 2 Jan 2018. 
Urbis. 2015. Protecting the north: The benefits of cyclone mitigation. Brisbane: Urbis. https://www.suncorp.com.au/insurance/safety/ protecting-the-north.html. Accessed 18 Mar 2019.

VCOSS (Victorian Council of Social Service). 2017. Helping lowincome Australians access insurance: VCOSS submission to the Senate Inquiry into Australia's general insurance industry. Melbourne: VCOSS. https://vcoss.org.au/wp-content/uploads/ 2017/02/SUB240217_General-insurance-inquiry-FINAL.pdf. Accessed 18 Mar 2019.

Victorian Bushfire Reconstruction and Recovery Authority. 2009. Victorian Bushfire Reconstruction and Recovery Authority 100 day report. South Melbourne: State Government of Victoria.

Victorian Bushfire Reconstruction and Recovery Authority. 2010. Victorian Bushfire Reconstruction and Recovery Authority 15 month report. South Melbourne: State Government of Victoria.

Victorian State Government. 2010. Victorian Bushfire Appeal Fund 12 month report. Melbourne: Victorian Bushfire Appeal Fund. https://dhhs.vic.gov.au/publications/victorian-bushfire-appealfund-vbaf-reports. Accessed 13 Mar 2018.
Victorian State Government. 2011. Implementing the government's response to the 2009 Victorian Bushfires Royal Commission. Melbourne. https://www.parliament.vic.gov.au/papers/govpub/ VPARL2006-10No332ImplementingGovtResponse2011.pdf. Accessed 5 Jun 2018.

Victorian State Government. 2016. Victorian Bushfire Appeal Fund 2016 progress report. Melbourne: Victorian Bushfire Appeal Fund. https://www.dhhs.vic.gov.au/publications/victorian-bush fire-appeal-fund-vbaf-reports. Accessed 9 Feb 2018.

Victorian State Government. 2017. 'Insure it - it's worth it' campaign launched. https://www.emv.vic.gov.au/news/insure-it-its-worthit-campaign-launched. Accessed 18 Mar 2019.

Whittle, R., M. Walker, W. Medd, and M. Mort. 2012. Flood of emotions: Emotional work and long-term disaster recovery. Emotion, Space and Society 5(1): 60-69.

Worthington AC. 2015. Natural disasters and national natural disaster insurance: An Australian perspective. Report commissioned by the Australian Centre for Financial Studies. Melbourne: Griffiths University. 